animal was kept under observation for one week during which there was no relapse of tympany.

\section{USE OF HOMEOPATHIC MEDICINE IN ACUTE TYMPANITES IN A BLUE BULL (BOSELAPHUS TRAGOCAMELUS)}

\author{
V.M. Dhoot ${ }^{1}$, S.V. Upadhye ${ }^{2}$ and M.R.Pande ${ }^{3}$ \\ ${ }^{1}$ Officer-in-charge, Maharajbag Zoo, \\ ${ }^{2}$ Assistant Professor, \\ ${ }^{3}$ Zoo Keeper, Maharajbag Zoo, \\ College of Agriculture, Nagpur, Maharashtra, India.
}

Acute tympany in ruminants may occur as a result of sudden change in diet, excess consumption of green or waste food. Various allopathic drugs are available for treatment though homeopathic drugs are increasingly used these days by veterinarians because of their low-cost and negligible side effects. These drugs are also easy to administer and require no restraining. A case of acute tympanites in a blue bull and its successful treatment with homeopathic medicines is reported.

A blue bull belonging to Maharajbag Zoo, College of Agriculture, Nagpur, suffered from acute tympany. The bull showed symptoms of distended left paralumbar fossa, restlessness, kicking at belly, rolling on ground and laboured breathing. The body temperature recorded was $102^{\circ} \mathrm{F}$.

Left paralumbar fossa was prepared aseptically and with a 16gauge needle the rumen was punctured and gas was removed immediately. Injection Zeet $10 \mathrm{ml}$ intramuscular and injection Dextrose $10 \%$ 500ml were given intravenously. Liquid Bloatosil $100 \mathrm{ml}$ was given orally. The animal was kept fasting for 12 hours. Animals showed slight improvement in 24 hours but there was relapse of tympany the next day. Examination of ruminal liquor showed a pH of 6.2. The motility and density of ruminal microflora was nigligible. Same treatment was given and in addition to this turpentine oil $10 \mathrm{ml}$ and linseed oil $200 \mathrm{ml}$ were drenched orally. In the evening, the animal recovered and showed normal behaviour but unfortunately it again showed signs of tympany on the third day. A decision was taken to treat the blue bull with homeopathic medicines. Tr. Nuxvomica 200 orally 10 drops, two doses at two-hour interval and Tr. Cabro Veg 200 orally 10 drops once in between two doses of Nuxvomica.

Two doses of Nuxvomica and single dose of Carbo Vegetalis showed remarkable effect. The appetite was restored and the
Generally, tympany is caused due to excessive intake of leguminous plants, green plants, cereal crops, beans, cabbage, potato, soluble carbohydrates like sugar, molasses, left over boiled rice, fodder containing more proteins, calcium and lack of fibrous food (Chakrabarti, 1994). In the present case, tympany might have been caused due to excessive consumption of green grass. Chakrabarti (1994) also reported similar symptoms in domestic ruminants, however we did not come across any other report of tympany in blue bull.

In this case, rumen had to be punctured to relieve gases as well as to overcome pressure on diaphragm. As there is usually an increase in antihistamine levels, antihistaminic preparation of injection Zeet $10 \mathrm{ml}$ (intramuscularly) was given followed by injection Terramycin 10ml (intraruminal) to combat Streptococcus bovis. These organisms are normally present in the rumen and multiply when there is a decrease in the $\mathrm{pH}$ of rumen. Bloatosil, turpentine oil and linseed oil were used to reduce the surface tension. Tr. Nuxvomica 200, being a carminative drug, helped in relieving disturbance following over eating, abdominal discomfort and flatulence. Tr. Carbo Vegetalis 200 proved useful in ruminal stasis and tympany (MacLeod, 1992).

The successful use of Tr. Nuxvomica and Tr. Carbo Vegetalis in this case suggests that these homeopathic drugs can be used in wild ruminants for digestive tract disorders like tympany.

\section{Acknowledgement}

The authors are thankful to Dr. C.S. Chaudhari, Zoo Controller and Associate Dean, College of Agriculture, Nagpur for providing facilities.

\section{References}

Chakrabarti, A. (1994). Textbook of Clinical Veterinary Medicine $\left(2^{\text {nd }}\right.$ revised edition), pp. 328-337. Kalyani Publishers, New Delhi.

MacLeod, G. (1992). The Treatment of Cattle by Homeopathy, pp. 10, 124. B. Jain Publishers, Pvt. Ltd., New Delhi. 